\title{
Crop and food development through modern biotechnology techniques in Central America Development of food crops through the use of modern biotechnology techniques in Central America
}

\section{Giovanni Garro-Monge ${ }^{1}$}

Garro-Monge, G. Crop and food development through modern biotechnology techniques in Central America. Tecnología en Marcha. Edición especial inglés. Febrero 2016. Pág 54-69.

Original version published in spanish. Garro, G. Desarrollo de cultivos y alimentos por técnicas de biotecnología moderna en Centroamérica. Tecnología en Marcha. Vol. 25, Nº 5. Pág 40-54. 
Tecnología en Marcha,

Edición especial inglés. Febrero $2016 / 55$

\section{Key words}

Biotechnology; Genetically Modified Crops/Organisms (GMC/GMO); Central America; food safety and functional food.

\section{Abstract}

In the last decade, the adoption of Genetically Modified Crops (GMC) has increased in scale worldwide. The total area planted with biotechnological crops reached 365 million acres in 2010, while the number of farmers around the world who decided to produce crops with this technology increased as well.

At a regional level there have been different responses from government agencies, which have formulated rules and regulations in keeping with the realities of these countries. In Central America, the countries that are most involved in the development and cultivation of food biotechnology techniques are Guatemala (papaya), Honduras (beans and maize), and Costa Rica (cotton, soybean and pineapple). At a global level, the latter two were among the 29 countries with the most GMO crops in 2010. Some countries of the region have also implemented governmental regulatory structures through technical committees on Biosafety.

The most important characteristics of these crops in terms of trade continue to be the provision of herbicide tolerance or pest resistance. However, the introduction of new modified products with good prospects in the market is also noteworthy.

These experiences with cultivation and Biosafety regulation at a regional level could lead to successful and progressive development of agricultural and food biotechnologies in the near future.

\section{Introduction}

Biotechnology has been used in food production for thousands of years, and is in fact one of the oldest techniques known. Use of yeast and bacteria to produce bread, wine and cheese are among the clearest examples in which live organisms (or parts of them) have been used to generate goods or services from the earliest times.

Biotechnology has experienced considerable evolution, and has become a leading field in Science, with many areas yet to be explored, thanks to the benefits it provides for society and the environment.

Biotechnology not only improves products through lower production costs or improved production processes, but also helps to provide solutions for the complex global food situation. Expectations for supplying food to the world's population are increasingly ambitious in terms of quantity and quality, and biotechnology offers safe alternatives which are environmentally sustainable and scalable.

\section{Definition}

Food improved with modern biotechnology, known worldwide as GMO (Genetically Modified Organisms), or Organismos Genéticamente Modificados (OGM) in Spanish, represent the breakthrough with the greatest commercial impact in the last 20 years of modern agriculture. These developments refer to the use of genetic engineering techniques that make it possible to purposefully insert gene sequences into genomes of crops or food, where they are integrated and express themselves as a new property of the plant. 
Implementation of these modern techniques has achieved several objectives, such as improving and increasing the speed of productive processes, creating food more quickly, improving the organoleptic properties and nutritional quality of the products, and inserting genes that are resistant to herbicides and pesticides. It has also been possible to achieve resistance to adverse environmental conditions such as drought, salinity, and the presence of heavy metals.

Even though these biotechnology techniques have made it possible to develop crops and food in a more targeted manner as compared to conventional genetic improvement techniques, they should be used as alternatives or complements to conventional techniques that the current development of $98 \%$ of vegetable and animal food consumed is based on (Garro, 2004).

\section{Food safety}

Food products improved through modern biotechnology techniques have caused about a great deal of controversy since they were introduced, due to general considerations related to their safety. Several environmental groups have published a considerable amount of information arguing against the use of these techniques, based on arguments which are easy to understand in commercial and ideological terms, but difficult to understand in scientific terms (Vidal, 2004).

Absolutely all products obtained through modern biotechnology techniques must undergo a series of studies (laboratory and field studies) before they are released to the market, while food products generated under conventional or organic conditions are not subjected to these studies (Konig et al., 2004).

This in-depth analysis of GMO has in fact produced much information which could help prevent many health problems caused by food produced through organic or conventional techniques (Garro, 2004).

These long-term tests are carried out in a standardized fashion by governmental and private institutions around the world (FDA, USDA, FAO, UNESCO, WHO). In terms of food safety, these analyses are focused basically on studying whether allergens have been introduced into the plant, or if pre-existing allergen levels of the crop have been modified.

To determine if this has happened, properties shared by allergens, such as their resistance to digestion, their prevalence in food, and their similarity to other allergenic proteins are analyzed through bioinformatics studies that allow the comparison of the new gene sequence with that of known allergens (ArgenBio, 2011)

All transgenic crops consumed today have been analyzed with respect to their environmental safety and food safety, including their allergenic potential.

Genetic engineering techniques have made it possible to eliminate harmful substances in certain crops of interest, as is the case with the allergenic properties of peanuts. Using RNA interference technology, US scientists were able to silence the gene that produces one of the most allergenic peanut proteins. In some lines, techniques such as ELISA even showed the total absence of this allergen, while at the same time proving that plant properties were not modified (ArgenBio, 2011).

Likewise, soybean crops have been treated to reduce their allergenic potential. Soybeans are a food that may produce allergic reactions in some persons, and in half of the cases this is due specifically to a protein called P34. A group of researchers recently proved that the expression of the corresponding gene may be silenced without modifying seed maturation or composition (ArgenBio, 2007). 
Thanks to successful analyses carried out in a timely fashion, none of the products released in the market for which modern biotechnology techniques were used have presented any health risks, showing that they are as safe as those derived from their conventional equivalents.

\section{Main properties used}

Food products improved through modern biotechnology have been introduced in the market with a wide variety of interesting properties. Among these properties, it is worth mentioning that characters of agronomic interest (first generation) have been modified to make improvements in food processing (second generation), and change elements of their composition related to nutrition (third generation). Among the best known agronomic properties are the genes that provide resistance to pests and tolerance to herbicides, thereby contributing to crop productivity and to reduce environmental pollution.

Recent studies have evaluated the actual impact of adopting biotechnological insect-resistant crops, and have concluded that this technology produces less environmental impacts than traditional crops, while increasing total productivity.

Traxler et al. (2003) carried out economic impact studies in several regions of México and the United States on the introduction of GMO crops and the use of pesticides using Bt (Bacillus thurigensis) technology, which provides insect-resistant genes in plants. In cotton plantations attacked by the pink bollworm in Comarca Lagunera (Coahuila, México), for instance, pesticide use was reduced from 12 applications in the past (1996) with conventional technologies, to only 2 applications in 2001 in locations where the Bt technology was applied.

This accounted for savings close to $80 \%$ of total expenses as compared to crops where conventional techniques were used.

Techniques to provide resistance to several types of herbicides have been developed, although most of the seeds currently sold are resistant to glyphosate, a broad spectrum post-emergent herbicide with low environmental persistence. At a global level, through genetic engineering, cotton, soybean and corn species have been created which can tolerate this herbicide - a composite that acts on amino acid synthesis routes.

Glyphosate is an inhibitor that competes with the 5-enolpyruvylshikimate-3-phosphate synthase enzyme, which participates in the synthesis of aromatic amino acids that are essential for the synthesis of numerous proteins. This enzyme is found in plants and microorganisms, but not in animals. Resistance is obtained by introducing a slightly different gene obtained from the A. tumefaciens bacteria in the plant. This gene codes for a version of this enzyme that is not sensitive to the herbicide (Garro, 2010).

One of the commercial names of glyphosate is "Roundup", and the persons that developed this technology called glyphosate-tolerant crops "Roundup Ready" or "RR" (ArgenBio, 2007). Specifically, in 2005, the Monsanto company announced the creation generation of "Roundup Ready Flex" cotton, which is characterized by providing a wider frame for use for "Roundup" herbicides throughout the cultivation period, providing farmers with more flexibility and convenience.

In 1996 the first varieties of glyphosate-tolerant soybeans were registered in the National Registry of Cultivar Ownership in the name of the Nidera company, and in the 1997-98 growing season 4,324,000 acres were planted (ArgenBio, 2007). At present there are several seed firms that market a large number of soybean varieties with this property.

Likewise, the Bayer CropScience company has created an herbicide-resistant species, and obtained final authorization for its technology. This is known as Liberty Link, and makes plants 
ammonia-gluphosinate-tolerant, allowing for an efficient and extensive weed control (Bayer CropScience, 2011)

Glyphosate-tolerant corn species have been developed in the same way and were approved for commercial planting in 2004. Since then, their adoption has been increasing in a sustained manner, reaching 536,218 acres in the last growing season (almost 10\% of all transgenic corn) (ArgenBio, 2007). The latest data indicate that in the 2006-07 growing season over $70 \%$ of transgenic cotton planted in Argentina was glyphosate-tolerant (ArgenBio, 2007).

In addition to resistance to herbicides and insects, organoleptic properties have been introduced that improve the quality of processing or post-harvest handling (Pantanelli, 2007). Among them are delayed maturation (tomatoes, chili peppers) and elimination of russeting by changing enzymatic routes in crops such as potatoes, apples, pears and bananas. In Argentina, for instance, researchers at INGEBI-CONICET obtained a potato variety with a high level of russeting inhibition which is still under study (ArgenBio, 2007).

With respect to the modification of nutritional factors, it is worth noting the composition or increase of some food components, and increased beta-carotene and iron in cereals.

Monsanto has produced beta-carotene-rich rape and mustard seeds, and more recently scientists of the Rockefeller Foundation produced a variety of rice called Golden rice, which has been genetically modified to produce beta-carotene. This has been widely considered as an important strategy to control Vitamin A deficiency, since rice is a staple food among populations that show the greatest deficiencies of this vitamin; Golden Rice could help reduce this problem, although it will never be completely eliminated (Garro, 2010).

Some of the latest efforts, which still require further study, involve adding pharmacological products to food (known as oral or edible vaccines) and the production of human proteins in food.

Genetic modification has shown the capacity to produce anti-bodies that are used for diagnoses and treatment of several diseases. There are also developments in alfalfa, corn, rice, tobacco, bananas, and potatoes as biological producers of medicines, vaccines and plastic.

In 1995 experiments were undertaken with genetically modified potatoes to produce the protein that coats the hepatitis B virus, and rats fed with these potatoes displayed an immune response similar to that which the entire virus causes (Bioplanet, 2001).

In the United States, potatoes have been genetically modified that carry a vaccine against cholera whose structure and properties are similar to the E. coli enterotoxin. In these experiments it was observed that eating the transgenic tuber can inoculate individuals against this disease - according to a research team of Loma Linda University, California, in their trials with rats they produced antibodies against cholera, even when the potatoes were cooked (Garro, 2010).

Overall, as shown in Table 1, potatoes, tomatoes and other crops have been created which can produce antigens of the Norwalk virus (which causes diarrhea), the AIDS virus (HIV-1), the bacteria of cholera (Vibrio cholerae), and the rabies virus (Bioplanet, 2001; Brown, 1997).

At present, this strategy to produce vaccines embraces a broad range of pathologies and immunogenic peptides: rabies (G protein), CMV (glycoprotein-B), hepatitis B (HBsAg), Pseudomonas aeruginosa, Staphylococcus aureus, MEV, malaria, rotavirus, and even autoimmune diseases such as diabetes (GAD 65 and 67) (Garro, 2010). 
Table 1. Main human or animal vaccines expressed by transgenic plants

\begin{tabular}{|c|c|c|}
\hline Protein & Host plant & Comment \\
\hline B Hepatitis protein & Tobacco & $\begin{array}{l}\text { First vaccine expressed in plants, third } \\
\text { to reach the clinical trial phase. }\end{array}$ \\
\hline Rabies virus glycoprotein & Tomatoes & $\begin{array}{l}\text { First example of edible vaccine } \\
\text { expressed in vegetable edible tissues. }\end{array}$ \\
\hline E. coli enterotoxin & Tobacco, Potatoes & $\begin{array}{l}\text { First oral vaccine to reach the clinical } \\
\text { trial phase. }\end{array}$ \\
\hline $\begin{array}{c}\text { Protein of the capsids of the Norwa lk } \\
\text { viruses }\end{array}$ & Potatoes & $\begin{array}{l}\text { Second oral vaccine to reach the } \\
\text { clinical trial phase. }\end{array}$ \\
\hline Diabetes antigen & Tobacco, Potatoes & $\begin{array}{c}\text { Firs oral vaccine derived from an } \\
\text { autoimmune disease. }\end{array}$ \\
\hline Cholera toxin subunit B & Tobacco, Potatoes & $\begin{array}{l}\text { Firs oral vaccine expressed in } \\
\text { chloroplasts. }\end{array}$ \\
\hline $\begin{array}{l}\text { Cholera toxin subunits } B \text { and } A 2 \text {, rotavirus } \\
\text { and enterotoxins and enterotoxigenic } \\
\text { fusions of the E.coli fimbrial antigen }\end{array}$ & Potatoes & $\begin{array}{l}\text { First recombinant vaccine to protect } \\
\text { against several diseases. }\end{array}$ \\
\hline $\begin{array}{c}\text { Transmissible virus of swine } \\
\text { gastroenteritis }\end{array}$ & Tobacco, Corn & $\begin{array}{l}\text { First oral vaccine for protection of } \\
\text { animals }\end{array}$ \\
\hline
\end{tabular}

Source: Ma et al. 2003.

Edible vaccines offer multiple advantages over injections, as shown in Table 2, since plants can be cultivated locally at low cost, using traditional crops in a region. In addition, edible vaccines solve transportation and preservation problems, which are carried out in the same way as is done with the crops, are high-quality, and are less pollutant. Administration of edible vaccines may also be easier and less expensive - since they are relatively stable, the distribution of immunologically active materials is simplified.

Table 2. Comparative table of production systems of recombinant vaccines. Source: Ma et al. 2003.

\begin{tabular}{|c|c|c|c|c|c|c|c|}
\hline System & Total cost & $\begin{array}{c}\text { Production } \\
\text { time }\end{array}$ & Scalability & $\begin{array}{c}\text { Production } \\
\text { quality }\end{array}$ & Glycosylation & $\begin{array}{c}\text { Contamination } \\
\text { risks }\end{array}$ & $\begin{array}{c}\text { Storage } \\
\text { cost }\end{array}$ \\
\hline Bacteria & $\begin{array}{c}\text { Ledium } \\
\text { High }\end{array}$ & Short & High & Low & None & Endotoxins & Moderate \\
\hline Yeast & Medium & High & Medium & Incorrect & Low risk & Moderate \\
\hline $\begin{array}{c}\text { animal cell } \\
\text { cultures }\end{array}$ & Long & Very low & Very high & Correct & $\begin{array}{c}\text { Viruses, prions and } \\
\text { congenital DNA }\end{array}$ & High \\
\hline $\begin{array}{c}\text { Transgenic } \\
\text { animals }\end{array}$ & High & Very Long & Low & Very high & Correct & $\begin{array}{c}\text { Viruses, prions and } \\
\text { congenital DNA }\end{array}$ & High \\
\hline $\begin{array}{c}\text { Culture of } \\
\text { vegetable } \\
\text { cells }\end{array}$ & Medium & Medium & Medium & High & differences & Low risk & Moderate \\
\hline $\begin{array}{c}\text { Transgenic } \\
\text { plants }\end{array}$ & Very low & Long & Very high & High & Minor \\
differences & Low risk & Low \\
\hline
\end{tabular}


Tecnología en Marcha,

60 Edición especial inglés. Febrero 2016

\section{Functional foods}

A great deal of modified foods are currently found in the market, or are in the process of commercialization. One of the most interesting produce is "golden rice", enriched with betacarotene -a Vitamin A precursor- developed by a team headed by Dr. Ingo Potrykus, a Swiss scientist of worldwide renown. This rice is supposed to be a very effective way to fight blindness among children in countries with high poverty rates that are highly dependent of this crop as a staple food.

The Vitamin A provided by this rice is intended to prevent diseases caused by shortages of the vitamin - blindness, severe diarrhea, respiratory disease, and childhood diseases such as measles in African, Asian, and Latin American countries (Garro \& Lam, 2009).

Soybeans with a high content of oils with fatty unsaturated acids such as oleic acid and stearic acid have also been produced. They are usually oxydatively stable, have good flavor properties and positive effects on human health, as opposed to oils rich in polyunsaturated fatty acids (linoleic and linolenic acids) which have poor taste and low stability (Garro \& Lam, 2009).

Among the most interesting cases are products used as sweeteners, which are highly important in the market. Good examples of food improvements are tomatoes and lettuces containing thaumatin genes, extracted from Thaumatococcus danielli, or from monellin, originating from Dioscoreophyllum cumminsii. These have up to 1000 more sweetening power than sucrose.

Transgenic tomatoes have also been developed in the same way, with considerably delayed rotting of the fruit during its maturation (flavor savor); more viscous crushed tomatoes can be produced, which is very useful for the production of tomatoe juice, paste or ketchup.

Another common organoleptic problem is vegetable russeting. The biochemical foundation of this problem is the synthesis of the polyphenoloxidase enzyme, which produces melanic polyphenols. Transgenic potatoes have been obtained that have inhibited the synthesis of the polyphenoloxidase gene, producing tubers that take hours to discolor.

A transgenic eggplant has been produced to be used mainly in India -the second largest exporter of this crop- where eggplant is a staple food. However, eggplants are affected by various insects and diseases that may cause losses of up to $60 \%$ or $70 \%$ of the crop, requiring extensive use of insecticides. Production of Bt eggplant is expected to reduce insecticide applications to control fruit and sprout borers by $80 \%$ (James, 2009).

Another outstanding example is the production of apples which produce an anti-cavity protein as part of their development. This protein was isolated and the gene that produces the p1025 protein which occupies spaces between teeth is inserted and prevents cavity bacteria from growing.

Potatoes were also produced to which genes of an enzyme that increases glucose rupture and starch production are added. This has allowed production of glucose- and starch-rich potatoes, to be used in the processed food industry (Garro \& Lam, 2009).

Recently, SmartStax ${ }^{\mathrm{TM}}$ corn was produced, which is the result of a reciprocal licensing and collaboration in research and development agreement signed in 2007 between Monsanto and Dow AgroSciences.

SmartStax ${ }^{\mathrm{TM}}$ corn is a multi-gene product based on a total of eight genes. This is the most advanced biotechnological crop of stacked genes that has been approved so far, and is designed to provide maximum insect pest control in corn (both on the surface and underground), and also herbicide tolerance for weed control. SmartStax ${ }^{\mathrm{TM}}$ is a quadruple stack of approved products from the following genes: MON 89034 x TC1507 x MON x DAS-59122-7 (James, 2009): 
1) MON 89034 expresses the Cry2Ab and Cry $1 A .105$ proteins that complement each other in Lepidoptera pest control.

2) TC1507 expresses the Cry1F protein for Lepidoptera control, and the BAR gluphosinatetolerant protein.

3) MON 88017 expresses the Cry3Bb1 protein for control of corn rootworm (Diabrotica virgifera), and the CP4 glyphosate-tolerant protein.

4) DAS-59122-7 expresses a Cry34/35Ab1 binary protein for corn rootworm control (Diabrotica virgifera), and the BAR gluphosinate-tolerant protein.

In total, eight genes (cry2Ab, cry1A.105, cry1F, cry3Bb1, cry34, cry35Ab1, cp4 and bar) codify the three following events: surface insect control, subterranean insect control, and herbicide tolerance.

Among the multiple properties of transgenic plants, the most used has been herbicide tolerance; in 2009, it accounted for $62 \%$ of all acres planted with soybeans, corn, canola, cotton, beets and alfalfa, producing a more than 5\% increase over the yields produced in 2008 (James, 2009).

\section{0-2015 Development perspectives}

In many countries, the public perception of transgenic food has not been very favorable, for two principal reasons:

1) Fear in many traditional productive sectors in which transgenic crops and food represent a commercial threat, due to their low production costs they have shown worldwide - this is a socioeconomic problem, rather than a technological one.

2) Linked to this fear, many environmentalist groups have created anti-transgenic movements in which the general population and common consumers have been bombarded with irresponsible information, which is usually intended to sow dissension and myths about the safety of this technology - this is a problem of education.

As Aboites and Félix (2011) point out, negative public perception, which can be sees as indicating a lack of public awareness about the benefits of transgenic crops and food, is the main hindrance to biotechnology development, followed by infrastructure problems, institutional weaknesses, and technical-scientific limitations. This creates a scenario in which society may react with fear accentuated by risk, as well as by material insufficiencies and shortages (Aboites \& Félix, 2011).

Worldwide, it is clear that public perceptions are directly related to levels of education: the higher the educational level, the greater the acceptance of transgenic food products. It may therefore may be expected that consumer opinion will experience a dramatic change when people can qualitatively measure the difference between conventional and transgenic food.

Although transgenic food products have brought created a great deal of controversy between environmentalist groups and other organizations that oppose them, for others this seems like an excellent way to offer hope for the production of more and better food that may contribute, along with conventional food, to relieve global hunger, which, according to the FAO, affected one billion people in 2009. The amount of people suffering from hunger has continued to increase because as the global population grows, the per-capita area available for cultivation is increasingly reduced. 
All these are reasons to expect that agro-biotechnology should be regarded as a long-term, rather than a short-term, solution, to provide food and thus guarantee improvements in productivity and sustainable resource use, offering small farmers the opportunity to work efficiently.

Both crops and the number of agro-biotechnological producers are constantly increasing; for instance, for 2009 there were 600,000 more small farmers registered in India, representing the greatest increase of producers in the world (James, 2009).

It is expected that biotechnological crops will assist in achieving the Millennium Development Goals (MDGs) to reduce poverty by half by 2015. The increased income generated for small poor farmers by biotechnological crops in countries such as India and China provides a modest initial contribution towards improving their situation,

It is expected that in the coming years there will be increased development of modified food for the direct benefit of consumers, who will be able to appreciate the new properties of improved food, such as the presence of introduced proteins, and medicines or compounds which will improve people's diets.

\section{Global economic impact of GMO planting}

Although the economic crisis strongly affected all market sectors in the last few years, and levels of growth were lower than those of previous years, the levels of transgenic crops have reached figures that have never been seen before (Fig. 1).

The total global area planted with transgenic crops reached 181 million acres in 2014, compared to data from 2009, when 148 million acres were planted (James, 2014). For instance, in the case of soybeans, more than three-fourths of the global crop was transgenic soybeans (82\%), rather than conventional soybeans, and cotton was almost $70 \%$. Increases were see not only in the number of acres planted, but also increase upon 18 million in the number of farmers worldwide that decided to produce biotechnological crops.

There are 28 countries in which the greatest amount of transgenic crops are planted, and over half of the global population lives in these countries, i.e., $60 \%$ or a total of 4 billion people. More than half of the 1.5 billion acres cultivated in the world are in these countries, with 181 million acres $-12 \%$ of all cultivated acres-- dedicated to biotechnological crops (James, 2014).

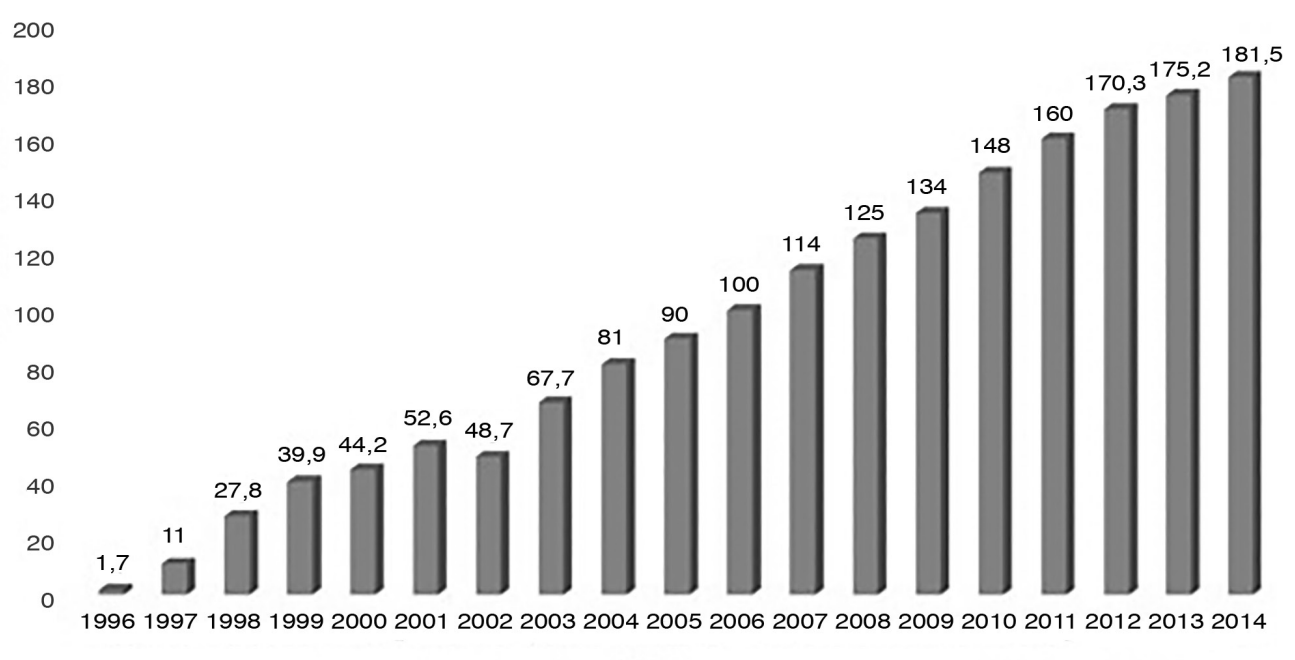

Años

Figure 1: Evolution in the size of the area planted with GMO crops worldwide in the period 1996-2014, according to James (2014). 
This increase over the last few years is due to the countries that were pioneers in biotechnological crops. This has to do with the application of stacked genes rather than single genes or one single variety or hybrid, especially in major crops such as corn and cotton in the principal agrobiotechnological countries.

These techniques meet the multiple needs of farmers and consumers, and are applied increasingly in 11 countries - in descending order of number of acres planted, they are: the United States of America, Argentina, Canada, Philippines, South Africa, Australia, México, Chile, Colombia, Honduras, and Costa Rica (James, 2009).

For instance, in 2009, a full $85 \%$ of the 86 million acres of corn cultivated in the United States were biotechnological crops. It is important to mention that $75 \%$ of the plantations were hybrids of two or three stacked genes, while only $25 \%$ were due to hybrids of a single gene.

With this and other examples, such as the Philippines, it is clear that stacked genes have come to play an important role in biotechnological crops; in addition, the large increase to 365 million acres planted with these crops is unprecedented in history, and makes biotechnological crops the agricultural technology with the fastest rate of adoption in history (James, 2009).

There was another increase directly related to the rise in the number of acres planted - that of farmers who benefited from biotechnological crops. In 200914 million farmers were benefitted in 25 countries, an increase of 700,000 from 2008, when there were 13.3 million such farmers.

Of the 14 million farmers benefitted in 2009, over 90\% were small poor farmers (most of them Bt cotton producers) from China, India (Bt cotton), and the Philippines (biotechnological corn), while the remaining million farmers were in industrialized countries as the United States and Canada, or from developing countries such as Argentina and Brazil. In China, the first studies indicate that an extra 10 million small poor farmers in this country could be secondary beneficiaries of Bt cotton (James, 2009).

Developing countries are increasingly dominating global agro-biotechnological production, being currently responsible for almost half (48\%) of the acres planted, compared to $44 \%$ of the 331 million acres planted in 2009 (151 million acres), and it can be anticipated that similarly significant growth will be seen in the future.

Five large developing countries in the three Southern continents, with a total population to 2.8 billion inhabitants, continued to be strong leaders globally, with around 140 million acres planted, equal to $43 \%$ of the global agro-biotechnological planting area: 52 million acres in Brazil, 52 million acres in Argentina, 20 million acres in India, 9 million acres in China, and 5 million acres in South Africa.

In total, these countries have 1.3 million people who fully depend on agriculture, including .millions of small poor farmers and landless peasants, who make up the great majority of poor people in the world. These countries have made considerable investments in agro-biotechnological research and development - as much as large multinational corporations.

It is important to emphasize that, of the 51.9 billion dollars in additional benefits generated by biotechnological crops for farmer's income during the first 13 years of their commercialization (1996-2008), half (26.1 billion dollars) was generated in developing countries and the other half (25.8 billion dollars) in industrialized countries (Brookes \& Barfoot, draft).

Between 1996 and 200851.9 billion dollars of economic benefit were created $-49.6 \%$ through increased productivity, and $50.4 \%$ through reduction in production costs.

In 2008, the total increase in production of the four main biotechnological crops (soybeans, corn, cotton and colza or canola oil) was 29.6 million metric tons, which would have required 25 million additional acres to produce if biotechnological crops had not been used. 
Biotechnology has already contributed to increase productivity and reduce production costs of current biotechnological crops, and has an enormous potential for the future, when it will be applied to essential crops such as rice and wheat, as well as to subsistence crops for the poor, such as yucca.

According to Brookes and Barfoot (in progress) in 2008 reached a total value of 9.2 billion dollars (4.7 billion in developing countries, and 4.5 billion in industrialized countries).

The benefits accumulated during the 1996-2008 period reached US\$51.9 million (US\$26.1 million in developing countries, and US\$25.8 million in industrialized countries). These figures include highly important benefits associated with the double cultivation of biotechnological soybeans in Argentina.

In 2010, the number of agro-biotechnological countries stayed at 29 following the integration of Costa Rica into the group in 2009, and the abandonment of Bt corn by Germany at the end of the 2008 season. In Costa Rica, biotechnological crops are exclusively produced for the seed export market, as is the case in Chile. However, since Costa Rica is one of the countries with the highest levels of production of biotechnological crops in the world, a new high of 10 agrobiotechnological countries was reached in Latin America (James, 2010).

In the 2010 statistics, the crops with the largest planted area did not changed significantly. The main transgenic crops continued to be soybeans, cotton, corn and colza or canola oil.

Among these four crops, the one that has the most acres planted continues to be soybeans, which has been planted in 181 million acres, or $50 \%$ of the total area dedicated to these four crops. On the other hand, 51 million acres of cotton were planted -i.e., 14\% of the total area; 115 million acres of corn, or $31 \%$ of the total area; and 17 million acres of canola, or $5 \%$ of the total area (Fig. 2) (James, 2010).

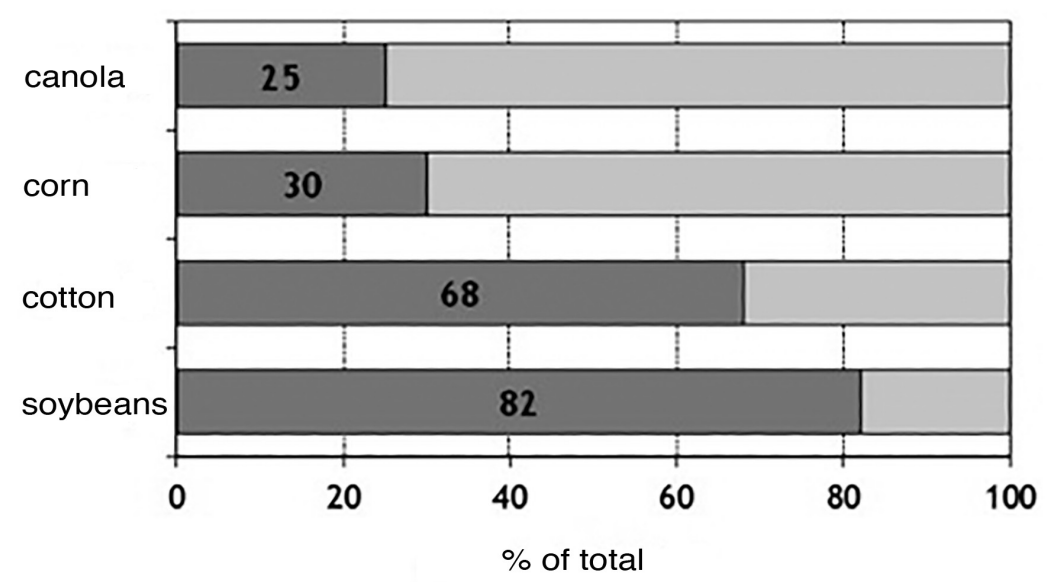

Figure 2. Main crops worldwide, and their share of the total area cultivated with transgenic crops, according to James (2014).

\section{Latin America's contribution to the global biotechnological crops market}

In Latin America, experience with cultivating improved varieties using modern biotechnological techniques has been increasing, and is having significant impacts on agricultural activities, mostly in terms of new management experiences (in some cases controlled), the reactivation 
of economies through the use of abandoned lands, and the creation of employment in socially disadvantaged regions.

However, even if this might be a good option for development and reactivating agriculture in poor regions, based on the experience generated so far, it would be an interesting strategy to evaluate the strategic integration of food crops that include innovative treatments, such as improvements in content (proteins, vitamins and amino acids), which are now in the final phases of research, and are expected to be in the market in the near future.

This type of food will have very high added value, and will have a remarkable effect on public perception, because consumers will have more options to improve their quality of life thanks to the consumption of functional food.

The largest Latin American producers of transgenic crops have been Argentina, Brazil, and México. The first two of these are among the four mega-producers worldwide, with 42 and 23 million acres planted respectively. Starting in 2002 countries such as Uruguay and Paraguay entered the market with a not-insignificant production of soybeans and corn: 4 million acres and 32.3 million $\mathrm{ft}^{2}$ planted, respectively. Honduras has seen growing production of transgenic crops since it began in 2002 when 1,235 acres of corn were planted, rising to 4,942 acres in 2003. Meanwhile, Colombia planted 4.942 acres in 2003 (James, 2004).

Clearly, these Latin American countries have bet on biotechnology. In most cases, this has been a national-level decision, making it possible to articulate various sectors on a government foundation, so that they may jointly take on roles as actors in national scientific development. Those that started this process earlier are currently enjoying the fruits of their decisions.

An example of this is the investment made by Brazil in research and development of biofuels, more than 30 years ago. As a result of this investment, Brazil is currently positioned as one of the leading countries worldwide in the use of this technology. Advantages are not limited only to this area: Brazil has also made highly significant contributions in issues related to vegetal and medical biotechnology.

Recently, an association among the Empresa Brasileña de Pesquisa Agropecuaria (EMBRAPA), the Universidad de Brasilia, the Escuela Paulista de Medicina and the Universidad Federal de Sao Paulo, is seeking to develop transgenic plants (soybeans) and animals (cattle) able to produce the "IX factor", the protein responsible for blood clotting, which is lacking in hemophilic patients.

The research is being carried out in Brasilia, in the laboratories of EMBRAPA, Recursos Genéticos y Biotecnología, one of the 40 units of the company, coordinate by the researcher Elíbio Rech (Alfa Editores, 2005).

Other events equally or more important for the medical industry and people's health are in development in countries in the region such as Argentina, Chile and Colombia, where biotechnology has been strongly promoted by several private and governmental institutions.

In Central America, existing biotechnology is mainly focused on tissue culturing, and in each country, institutions are working with molecular markers, either as an auxiliary tool for assisted improvement of crops, or as a tool aimed at the process of multiplication of pathogen-free plants (Aboites \& Félix, 2011). According to Aboites and Félix (2011), in all countries there is evidence of in vitro conservation, and even cryoconservation, although genetic engineering activities at the level of laboratories, or as part of academic programs, are only found in Guatemala (papaya), Honduras (beans), and Costa Rica, the only country that shows evidence of covering the complete range of biotechnologies. 
Tecnología en Marcha,

66 Edición especial inglés. Febrero 2016

\section{The experience of Costa Rica in biotechnology}

In Costa Rica, transgenic seeds are reproduced exclusively for exportation. This is true in the case of cotton (around 2,471 acres), soybeans (less than 49 acres), and in the past, in the case of seed corn. In Costa Rica, biotechnological development has been carried out by public universities.

Field trials (on less than 49 acres) have been conducted for pineapple crops modified with increased $\beta$-carotene. A recent study found 195 biotechnology research projects in this country (Valdez et al. 2004). The same study identified the most important categories of projects in this area; bio-agro accounts for 39\%, human bio-health accounts for 30\%, and food processing accounts for $7 \%$.

Research projects are underway with plantain, bananas and rice (model projects of the University of Costa Rica) aimed at solving important problems in these crops, which may be de-regulated in the future (allowing their commercial use), and whose use would have important benefits from the agronomic, economic, social and environmental perspectives - when genetic resistance to different pests is obtained, for instance, use of chemical pesticides would be considerably reduced.

Along with research efforts, public universities have worked on the dissemination and training of human resources in various areas of biotechnology. In 1997, the School of Biology of the Instituto Tecnológico de Costa Rica opened the career of Engineering in Biotechnology. To date, 362 professionals have graduated in this area, who are quite successful in finding work in both private companies and public institutions; their contribution to the development of biotechnology in Costa Rica will be highly valuable.

At the Central American level, Costa Rica occupies first place in terms of the formation of professionals in this area, with $64 \%$ and $68 \%$ of doctoral degrees and Master of Science degrees in biotechnology, followed by Honduras, Nicaragua, Guatemala, Panamá and, finally, El Salvador, according to data from Aboites and Félix (2011). With regards to infrastructure, once again Costa Rica leads with 33\% of the research institutes, and over half of the private institutes in the zone, followed by Nicaragua, Guatemala, Honduras, Panamá, and El Salvador.

Aboites and Félix (2011) also point out that Costa Rica is the only Central American country that has a policy to promote linkages of scientific and technological aspects of biotechnology with the productive sector in a systematic way, and that it is the only country where linkages of thirdgeneration biotechnologies with the productive sector are documented, as, for instance, in the case of the Centro Nacional de Innovaciones Biotecnológicas (CENIBiot) (Aboites \& Félix, 2011).

According to Trigo and Villarreal (2009), biosafety policies are classified in three categories, and using these categories it is clear that Central America, and specifically Costa Rica, is more focused on a preventive policy than on a promotional or neutral policy (Table 3).

With respect to biosafety policies in Costa Rica for the production of crops and food, commercialization has not been authorized for any transgenic organism to be used in agriculture. There are preventive policies in the country (Table 4) for these organisms in the Phytosanitary Protection Law ( $N^{\circ}$ 7664), and every research project or for the reproduction of seeds is first revised by the Biosafety National Technical Commission, which carries out risk evaluations and issues pertinent recommendations for the implementation of each activity under conditions of security which make it possible to prevent risks related to the introduction of any transgenic organism in the national environment. 
Table 3. Central America: biosafety policies for transgenic crops, 2009.

\begin{tabular}{|c|c|c|c|}
\hline Country & Policies for promotion & Neutral policies & Preventive policies \\
\hline & $\begin{array}{l}\text { Evaluations based } \\
\text { exclusively on } \\
\text { information generated } \\
\text { through approval in } \\
\text { other countries. Risk } \\
\text { analysis is not based on } \\
\text { a priori perceptions. }\end{array}$ & $\begin{array}{l}\text { Case by case } \\
\text { evaluations based } \\
\text { on proven risks or } \\
\text { scientific uncertainties } \\
\text { and expected risks } \\
\text { linked to the novelty } \\
\text { of the process of } \\
\text { transformation. }\end{array}$ & $\begin{array}{l}\text { Case by case evaluation } \\
\text { based on proven risks or } \\
\text { scientific uncertainties, } \\
\text { where expected risks } \\
\text { are linked to the novelty } \\
\text { of the process of } \\
\text { transformation. }\end{array}$ \\
\hline $\begin{array}{l}\text { Guatemala } \\
\text { El Salvador } \\
\text { Honduras } \\
\text { Nicaragua } \\
\text { Costa Rica } \\
\text { Panamá }\end{array}$ & & $\begin{array}{l}\sqrt{ } \\
\sqrt{ }\end{array}$ & $\begin{array}{l} \pm \sqrt{ } \\
\pm \sqrt{ } \\
\pm \sqrt{ } \\
\pm \sqrt{ }\end{array}$ \\
\hline
\end{tabular}

Note: $\pm \sqrt{ }$ Although a biosafety policy has not been defined, this seems to be a preventive strategy of a political nature.

Source: Trigo and Villarreal, 2009.

Table 4. Legal framework related to biotechnology, 2005.

\begin{tabular}{|c|c|c|c|c|c|c|c|}
\hline Aspect & Guatemala & El Salvador & Honduras & Nicaragua & Costa Rica & Panamá & Total \\
\hline $\begin{array}{c}\text { Biosafety } \\
\text { (specific } \\
\text { instruments) }\end{array}$ & $\begin{array}{c}\text { MAGA } \\
\text { Ministerial } \\
\text { agreements } \\
393-98 \text { and } \\
476-98\end{array}$ & & $\begin{array}{c}\text { SERNA } \\
\text { bill- final } \\
\text { draft being } \\
\text { prepared }\end{array}$ & $\begin{array}{l}\text { Bill } \\
\text { submitted } \\
\text { to the } \\
\text { National } \\
\text { Assembly }\end{array}$ & $\begin{array}{c}\text { MAG } \\
\text { decree with } \\
\text { Rules and } \\
\text { Regulations } \\
\text { for } \\
\text { agricultural } \\
\text { biosafety } \\
32486 \text { - } \\
2005\end{array}$ & $\begin{array}{c}\text { 48-2002 } \\
\text { National } \\
\text { Biosafety } \\
\text { Commission. } \\
\text { Resolution. } \\
\text { ANAM } \\
502 \\
\text { Biosafety } \\
\text { framework }\end{array}$ & -1 \\
\hline $\begin{array}{c}\text { Cartagena } \\
\text { Protocol }\end{array}$ & Ratified & Ratified & $\begin{array}{l}\text { Not yet } \\
\text { ratified }\end{array}$ & Ratified & $\begin{array}{l}\text { Not yet } \\
\text { ratified }\end{array}$ & Ratified & -1 \\
\hline Biodiversity & $\begin{array}{c}\text { Dis. 4-89; } \\
\text { 5-95; 101- } \\
96 ; \\
\text { 68-72; 68-86 } \\
\text { Ams. 177- } \\
95 ; \\
722-01\end{array}$ & $\begin{array}{c}\text { Dis. 844-94; } \\
\text { 579-05; } \\
\text { 233-98 }\end{array}$ & & Bill $b$ & $\begin{array}{c}\text { Laws 7317- } \\
92 \text { Law } \\
\text { 7788-98 }\end{array}$ & Law No 2-95 & -1 \\
\hline Seeds & $x$ & & & & $x$ & & -1 \\
\hline $\begin{array}{l}\text { Biotechnology } \\
\text { Commission }\end{array}$ & 1 & 1 & 1 & & 1 & 1 & \\
\hline $\begin{array}{l}\text { Biosafety } \\
\text { Commission }\end{array}$ & 1 & 1 & 1 & 1 & 1 & 1 & \\
\hline
\end{tabular}


The Biosafety National Technical Commission (CTNBio) was created 13 years ago (Decree $\mathrm{N}^{\circ}$ 26921 of March 20, 1998) and is made up of representatives of public institutions, such as the MAG Biotechnology Management Office, the National Seed Office of the MICIT, the Ministry of Public Health, and representatives of the Academy of Sciences.

Recently, the composition of the commission was modified to include representatives of the Federation for Environment Conservation, and of the Biosafety Coordination Network (Decree $N^{\circ}$ 31946 of October 4, 2004). The Commission has actively participated in international congresses and meetings about biosafety in with organizations such as the FDA, the USDA and the Codex Alimentarius, an international reference body for food biosafety and food labeling issues.

In addition, with the support of academic, and other public institutions, the CTNBio has generated various dissemination of information and debates about modern biotechnology issues.

Currently, the CTNBio has received international support from the United Nations Environment Programme (UNEP) and the Global Environment Fund (UNEP-GEF) to implement the Cartagena Protocol on Biosafety of modern Biotechnology, based on the Convention on Biodiversity; this project is mainly focused on strengthening the infrastructure of relevant authorities in the management of the implementation of the Cartagena Protocol.

In parallel with these efforts, a project called Multi-country capacity building for complying with the Cartagena Protocol (Construcción de capacidades multipaís para el cumplimiento del protocolo de Cartagena - Lac-Biosafety) financed by the UNEP-GEF, in which several Latin American countries (Brazil, Colombia, Perú) and Costa Rica are carrying out different types of research whose results will be used as important inputs for decision makers in approval of requests for planting GMOs in the participating countries.

As a result, civil society has had a presence in fora, workshops and courses in which it has had the chance to express its opinions and concerns about the advantages and potential negative effects of adopting these technologies. A national project aimed at extending regulations to other areas of biotechnological application (the environment, public health, livestock activities) is currently under discussion.

In the framework of national biosafety and scientific research on modern biotechnology issues, such as transgenic crops and food, there have been some very positive experiences that allow strengthening and integrating of important ideas and procedures that will strengthen the country's scientific development.

This national scenario, along with experiences in the rest of Latin American countries, may bring about positive developments for agricultural and food biotechnology.

Several institutions have set a goal to strengthen biotechnology programs, which must be a common goal of local governments in order to have integral, articulated visions that make it possible to develop national strategies, rather than simple individual efforts which end in frustration or are subjected to intricate procedures before they are accepted and validated by the general population.

\section{Bibliography}

ArgenBio (2007). Cultivos tolerantes a herbicidas (TH). Accessed: Sept., 2011. At: http://www.argenbio.org/h/biotecnologia/12.php

ArgenBio (2007). Alergias alimentarias. El Cuaderno de Por qué Biotecnología. Edición Nº 8.

ArgenBio (2011). Cultivos transgénicos, lo que hay y lo que vendrá. El Cuaderno de Por qué Biotecnología. Edición $N^{\circ} 130$ 
Aboites, G. \& Félix, G. (2011). Centroamérica: Uso de semillas Genéticamente Modificadas e Incremento del Ingreso de los Agricultores. México, D. F.: Comisión Económica para América Latina y el Caribe (CEPAL).

Alfa Editores (2005). Empresa brasileña producirá proteína contra la hemofilia mediante soya y vacas transgénicas. Accessed at: www.alfa-editores.com.

Bayer CropScience (2011). BioScience, Soluciones integrales y más. Accessed: Sept. 2011. At:

http://www.bayercropscience.com.uy/institucional.php?contentID=16

Bioplanet (2001). Plantas modificadas: Y de postre... una vacuna. Accessed: Sept., 2011. At:

http://www.bioplanet.net/magazine/bio_mayjun_2001_mayjun_industria.htm

Brookes, G. y Barfoot, P. En preparación. Cultivos Transgénicos: El Impacto Global Socio-económico y Ambiental de los Años 1996-2009. Economics.

Brown, K. (1997). La elaboración de vacunas de bajo costo para uso masivo. Noticias de Seguridad (12): 31-34.

Garro G. (2004). Biotecnología moderna e inocuidad alimentaria. Alimentaria 75: 34-37. Septiembre-Octubre.

Garro, G. \& Lam, K.M. (2009). Aplicación de la biotecnología moderna en la producción de alimentos de mayor valor nutricional. Alimentaria (101): 29-33.

Garro, G. (2010). Ingeniería Genética de Plantas: Aspectos generales, aplicaciones y prácticas de laboratorio. Material de Apoyo. Cartago: Instituto Tecnológico de Costa Rica. Pp. 76.

ICA (2004). Evaluación de los riesgos potenciales para introducir y comercializar semillas de algodón con las tecnologías conjuntas (Bollgard) + (Roundup Ready). Documento de Trabajo. Bogotá: Instituto Colombiano Agropecuario. $11 \mathrm{p}$.

James, C. (2004). Global Status of Commercialized Biotech/GM Crops: 2004. ISAAA Briefs No. 32. Ithaca, NY: ISAAA. James, C. (2009). Global Status of Commercialized Biotech/GM Crops: 2009. ISAAA Brief No. 41. Ithaca, NY: ISAAA. James, C. (2010). Global Status of Commercialized Biotech/GM Crops: 2010. ISAAA Brief No. 42. Ithaca, NY: ISAAA. James, C. 2014. Global Status of Commercialized Biotech/GM Crops: 2014. ISAAA Brief No. 49. ISAAA: Ithaca, NY.

Konig, A.; Cockburn A.; Crevel, R.; Debruyne, E.; Grafstroem, R.; Hammerling, U.; Kimberg, I.; Knudsen, I.; Kuiper, H.; Peijnenburg, A.; Penninks, A.; Poulsen, M.; Schauzu, M. \& Wal, J.M. (2004). Assesment of the safety of foods derived from genetically modified (GM) crops. Food and Chemical Toxicology 42: 1047-1088.

Ma, J.; Drake, P. \& Christou, P. (2003). The production of recombinant pharmaceutical proteins in plants. Nature Reviews-Genetics, Vol. 4.

Ocando, O. (2005). Algodón Genéticamente Modificado. 1 ed. Bogotá: AGROBIO.

Pantanelli, A. (2007). Alimentos fortificados y enriquecidos. Revista Alimentos Argentinos 14: 1-5.

Traxler, G.; Godoy-Avila, S.; Falck-Zepeda, J. \& Espinoza-Arellano, J. (2003). Transgenic Cotton in Mexico: Economic and Environmental Impacts. En: Kalaitzandonakes, N. (ed.). Economic and Environmental Impacts of First Generation Biotechnologies. New York: Kluwer Academic.

Trigo, E \& Villarreal, F. (2009). La agrobiotecnología en las Américas: una mirada a la situación actual y a las tendencias futuras. San José: IICA (ISBN 13: 978-92-9248-030-1).

Valdez, M.; López, R. \& Jiménez, L. (2004). Estado actual de la biotecnología en Costa Rica. Rev. Biol. Trop. 52(3): 733-743. 